\title{
Geosmithia-Ophiostoma: a New Fungus-Fungus Association
}

\author{
Alessia L. Pepori ${ }^{1}$ - Priscilla P. Bettini ${ }^{2}$. Cecilia Comparini ${ }^{1,3} \cdot$ Sabrina Sarrocco $^{4}$. \\ Anna Bonini $^{3}$ - Arcangela Frascella ${ }^{2} \cdot$ Luisa Ghelardini $^{1,3} \cdot$ Aniello Scala $^{3}$. \\ Giovanni Vannacci ${ }^{4} \cdot$ Alberto Santini $^{1}$ (i)
}

Received: 29 June 2017 / Accepted: 22 August 2017 /Published online: 5 September 2017

(C) The Author(s) 2017. This article is an open access publication

\begin{abstract}
In Europe as in North America, elms are devastated by Dutch elm disease (DED), caused by the alien ascomycete Ophiostoma novo-ulmi. Pathogen dispersal and transmission are ensured by local species of bark beetles, which established a novel association with the fungus. Elm bark beetles also transport the Geosmithia fungi genus that is found in scolytids' galleries colonized by $O$. novo-ulmi. Widespread horizontal gene transfer between $O$. novo-ulmi and Geosmithia was recently observed. In order to define the relation between these two fungi in the DED pathosystem, O. novo-ulmi and Geosmithia species from elm, including a GFP-tagged strain, were grown in dual culture and mycelial interactions were observed by light and fluorescence microscopy. Growth and sporulation of O. novo-ulmi in the absence or presence of Geosmithia were compared. The impact of Geosmithia on DED severity was tested in vivo by coinoculating Geosmithia and O. novo-ulmi in elms. A close and stable relation was observed between the two fungi, which may be classified as mycoparasitism by Geosmithia on
\end{abstract}

Electronic supplementary material The online version of this article (https://doi.org/10.1007/s00248-017-1062-3) contains supplementary material, which is available to authorized users.

Alberto Santini

alberto.santini@cnr.it

1 Institute for Sustainable Plant Protection (IPSP-CNR), via Madonna del Piano 10, 50019 Sesto Fiorentino, FI, Italy

2 Department of Biology, University of Florence, via Madonna del Piano 6, 50019 Sesto Fiorentino, FI, Italy

3 Department of Agri-Food Production and Environmental Science (DiSPAA), University of Florence, Piazzale delle Cascine 28, 50144 Florence, Italy

4 Department of Agriculture, Food and Environment (DAFE), University of Pisa, via del Borghetto 80, 56124 Pisa, Italy
O. novo-ulmi. These results prove the existence of a new component in the complex of organisms involved in DED, which might be capable of reducing the disease impact.

Keywords Biological control · Dutch elm disease (DED) . Fungus-fungus interaction - Geosmithia spp. · Mycoparasite · Ophiostoma novo-ulmi

\section{Introduction}

Every species is intricately involved with a myriad of associates - some obligate, some facultative - that profoundly influence their evolution, physiology, and life history [1].

Dutch elm disease (DED) is a highly destructive vascular disease, which caused an extensive loss of mature elms in Europe, Asia, and North America during the twentieth century. The disease is caused by fungi of the genus Ophiostoma (Ascomycota, Ophiostomatales) and, in particular, by Ophiostoma ulmi (Buisman) Nannf and Ophiostoma novoulmi Brasier (ONU) [2]. Pathogen spreading and infection of suitable hosts are mainly ensured by elm bark beetles (EBB) (Coleoptera: Curculionidae, Scolytinae) [3]. The synchrony between the life cycles of host tree, fungus, and EBB allows vectors to disseminate $\mathrm{ONU}$ when host plants are most prone to infection and temperatures favorable for fungal growth, thus boosting the pathogen's aggressiveness [4]. Moser et al. [5] showed that phoretic mites carried by EBB in turn transport ONU conidia, ascospores, and in some cases hyphae attached to their body surfaces, in sporothecae and in the digestive system. Mites may therefore contribute to DED 
transmission by spreading the fungus within the gallery system, enhancing ONU sexual reproduction and promoting an increase in genetic diversity through the fertilization of protoperithecia. Moreover, mites may contribute to increase the spore load beyond the threshold required for infection [5].

The virulence of ONU might be negatively affected by the presence of a family of naturally occurring viruses, known as "d-factors," found in the fungus cytoplasm [6] and able to prevent ONU from infecting healthy elms [7]. O. novo-ulmi isolates carrying these viruses exhibit slow, ragged growth, as well as a reduction in sporulation, perithecia production, and viability of conidia $[8,9]$. In Europe, the virus was prevented from spreading into the ONU population, probably via the acquirement of the sexual compatibility type (MAT-1) and vegetative compatibility (vic) loci from $O$. ulmi [10]. Sexual reproduction alone helps to eliminate virus infection in ONU [11] leading to a rapid increase in the diversity of vegetative compatibility phenotypes [12], which reduces virus transmission.

The DED pathosystem is therefore a complex of interactions involving several other organisms in addition to the host plant, the pathogen, and the vector, ideally the entire EBBs' holobiont [1] as well as the d-factor viruses, whose interplay influences the outcome of the infection.

EBB also transport species of the genus Geosmithia (Ascomycota: Hypocreales) [13], a monophyletic morphogenus of anamorphic ascomycetes that currently includes 32 published and at least 20 unpublished species of mitosporic fungi [14-19]. Geosmithia fungi may live as saprobes on various plant substrates, in soil or foodstuffs, and as true plant endophytes and are in most cases insectassociated [14, 17, 19, 20]. Several Geosmithia species have, at least for some parts of their lives, the same habitat as ONU on dying elms, although they occupy different ecological niches [21].

The existence of a more complicated relationship between ONU and Geosmithias than just occupying the same habitat and having the same vectors has recently been suggested by the discovery of widespread horizontal gene transfer (HGT) of a genomic fragment comprising the cerato-ulmin $(\mathrm{cu})$ gene between the two fungi [22]. Cerato-ulmin, a class II hydrophobin of about $8 \mathrm{kDa}$ produced by the pathogens O. ulmi, O. novo-ulmi, Ophiostoma himal-ulmi, and by the non-pathogen Ophiostoma quercus [23, 24], might play a role in DED by improving the fitness of the fungus [25].

Several hypotheses were made on the ecological role of Geosmithia spp. on host trees, but no conclusive evidence has been provided [17, 20,26]. The aim of the present study was to examine the occurrence of a relationship between Geosmithia spp. and some Ophiostomatoid fungal species that have the same host plants and vectors and to define the nature of this relationship. The potential consequences of such a relationship on the DED pathosystem are also discussed.
The study focused on the "elm system," comprising species of Ophiostoma and Geosmithia specific to elms. The elm system was put in comparison with systems comprising Geosmithia and Ophiostomatoid species from other host plants as oak and conifers ("non-elm systems").

\section{Materials and Methods}

\section{Fungal Strains and Media}

The fungal species and strains included in this study are reported in Table 1. For the sake of brevity, in this paper, the term Ophiostomatoid fungi will be indistinctly used to refer to fungal species in orders Ophiostomatales and Microascales that share morphological analogies as the result of convergent evolution due to their association with insect vectors [28].

Short-term stock cultures were maintained on malt extract agar (MEA 2\%, Oxoid, Basingstoke, UK) at $4{ }^{\circ} \mathrm{C}$ and subcultured at 2-week intervals. Long-term stock cultures were maintained on MEA slopes at $-20^{\circ} \mathrm{C}$. Fungal growth rate in dual culture was assessed on MEA and Czapek Dox Agar (CZD, Oxoid, Basingstoke, UK), while mycelial interactions and ONU sporulation were studied in dual cultures growing on elm sapwood agar (ESA) or 2\% MEA [29].

\section{Fungal Growth Rate in Dual Culture (Experiment a)}

The reciprocal effect of the presence of Geosmithia spp. or Ophiostoma spp. on the growth rate of the other species was assessed in dual culture in several trials designed as follows. For each fungal combination, three Petri dishes $(90-\mathrm{mm}$ diameter) filled with $20-\mathrm{ml}$ substrate were inoculated by placing two 6-mm diameter mycelial plugs (one of Geosmithia spp. and one of Ophiostoma spp.), obtained from the edges of actively growing fungal cultures, about $1 \mathrm{~cm}$ apart from each other near to the center of dish. Cultures were incubated in the dark at $20{ }^{\circ} \mathrm{C}$ and two radii of each colony on the growing edge opposite to the other fungus were measured after $48 \mathrm{~h}, 3,5$, and 8 days. Three plates per isolate were inoculated with two identical plugs as a control. Daily radial growth rates were compared by one-way ANOVA (Statistica 10, StatSoft Inc.).

Eight Ophiostoma spp. isolates (four ONU and four O. quercus), 11 species of other Ophiostomatoid fungi, and nine Geosmithia spp. isolates (five from elms and four from other trees) were combined in six trials, where Geosmithia from elm and from other trees were grown in dual culture with species from the three Ophiostoma groups (Table 1). Fungal combinations from the non-elm system (oak and conifers) were cultured on both $2 \%$ MEA and CZD, while fungal combinations from the elm system were grown on $2 \%$ MEA. 


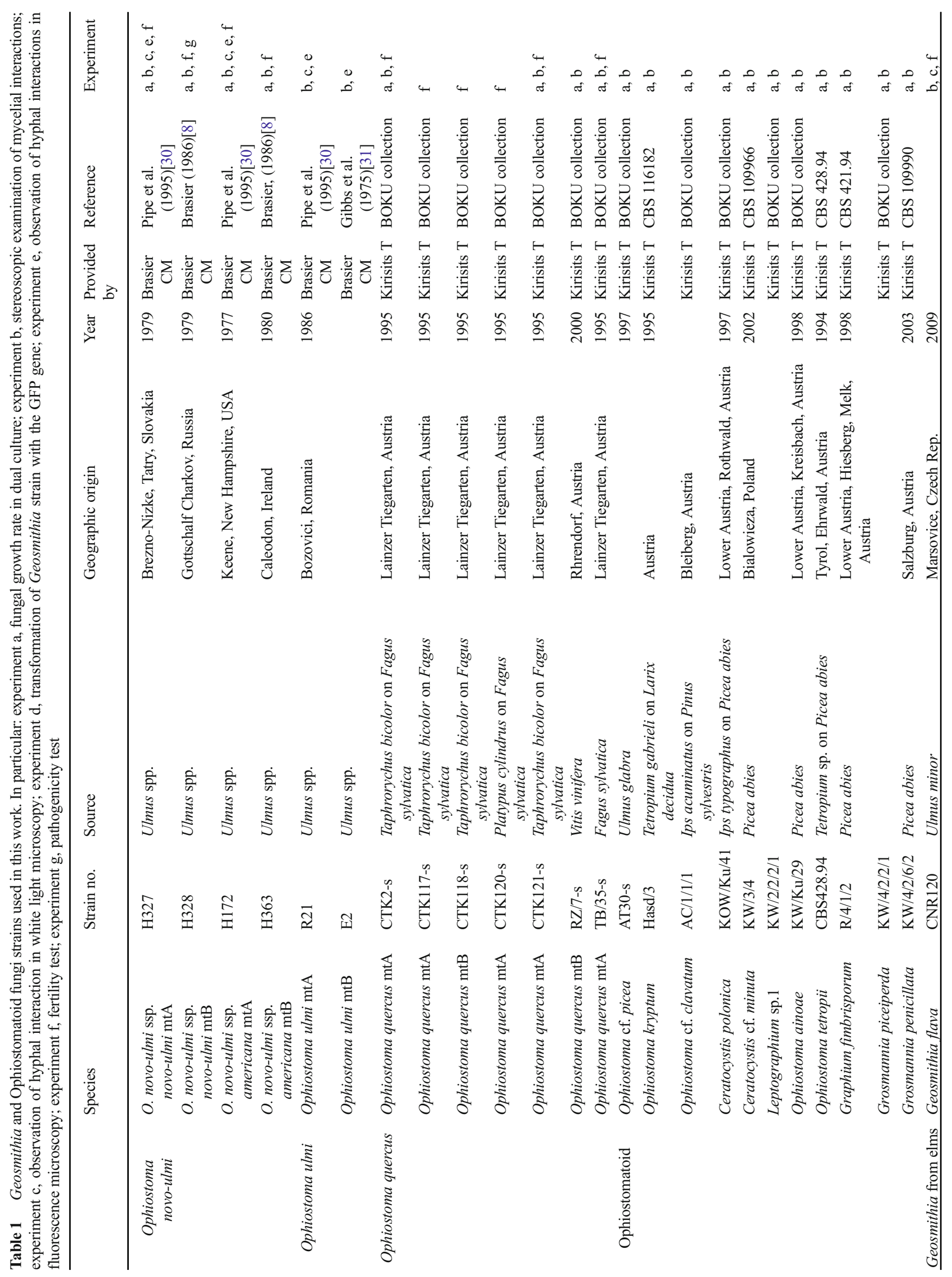




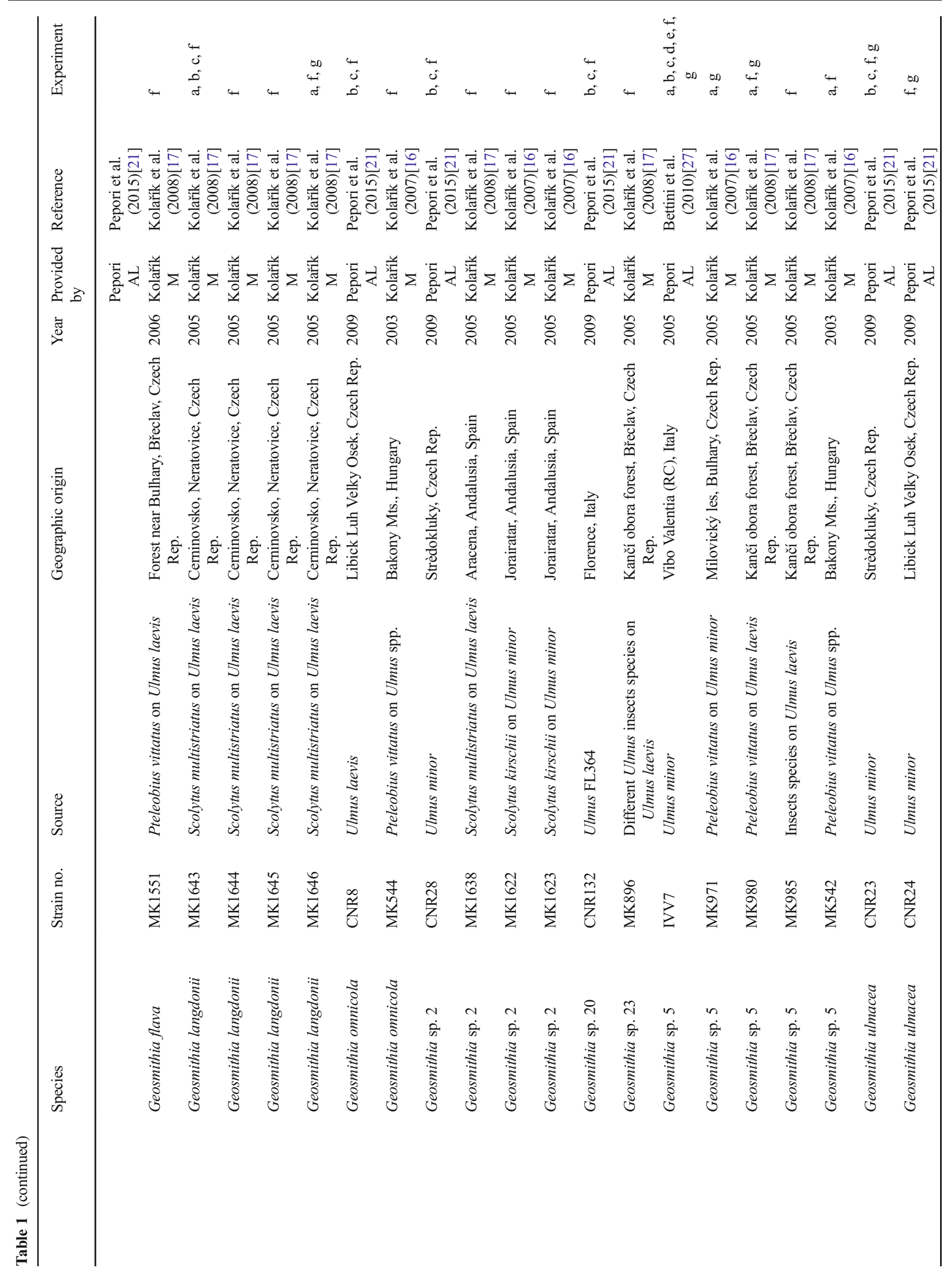



b)

In order to determine the existence of a recognition system between Ophiostomatoid fungi and Geosmithia, various species of Ophiostomatoid fungi were grown in dual culture with Geosmithia spp. Inoculations were performed in $90-\mathrm{mm}$ diameter Petri dishes containing $20 \mathrm{ml}$ of substrate (ESA and $2 \% \mathrm{MEA}$ ) as in Experiment a. Three replicates per each fungal combination and medium were prepared and incubated at room temperature in diffuse natural daylight. ESA was used since it had proved very effective for discriminating vegetative compatibility reactions in $O$. novo-ulmi $[29,32]$, while MEA is a common medium for growing Geosmithia spp. Colonies were visually examined after 5 and 10 days for the presence of an antagonism zone or a reaction zone in the region of mycelial contact [32,33]. Ten Ophiostoma spp. isolates (four ONU, four $O$. quercus, and two O. ulmi), 11 Ophiostomatoid fungi, and ten Geosmithia spp. isolates (six from elms and four from other trees) were combined in dual cultures in eight different trials (Geosmithia strains from elm or from other trees were cultivated with fungi from the four Ophiostoma groups) (Table 1).

\section{Observation of Hyphal Interactions in White Light Microscopy (Experiment c)}

The mycelial interactions between several Geosmithia spp. and strains with different $O$. ulmi and O. novo-ulmi strains were studied by white light microscopic observations.

Microscope slides (three per each Ophiostoma/Geosmithia combination) covered by a water-agar film $(2 \% w / v)$ were inoculated with two mycelial plugs (6 $\mathrm{mm}$ in diameter) obtained from the edges of actively growing fungal cultures, placed about $1 \mathrm{~cm}$ apart from each other. Microscope slides were observed after 2-day incubation $\left(20^{\circ} \mathrm{C}\right.$ in the dark) with a Zeiss Axioscop 50 optical microscope equipped with a Nikon digital camera. Images were processed with the Nikon Digital Sight DS-L1 software.

\section{Transformation of Geosmithia sp. 5 "IVV7" with the Green Fluorescent Protein (GFP) Gene (Experiment d)}

A GFP-tagged Geosmithia strain was obtained to gain a clearer and more detailed vision of the interactions between hyphae of the two fungi. Insertion of the GFP gene into the IVV7 isolate of Geosmithia sp. 5 was achieved through Agrobacterium tumefaciens - mediated transformation by using strain AGL-1 (kindly provided by Prof. A. Sesma, Universidad Politécnica de Madrid, Spain) containing the pCAMBgfp vector that includes a modified GFP (SGFP) and the hygromycin resistance gene [34]. Transformation 
was performed according to [34], while stabilization of transformants was carried out as in [35]. Eight independent IVV7-GFP clones were obtained and GFP expression was observed under fluorescence using a Leica MZ FLIII microscope equipped with a mercury lamp and GFP filters (excitation filter at 480/40 and a barrier filter at 510-nm LP). The number of insertions of the pCAMgfp plasmid was determined by southern hybridization using a digoxigenin-labeled GFP probe [27] (not shown). The growth rates of the IVV7GFP clones and of their parental isolate were determined by inoculating MEA plates with 7-mm diameter mycelial plugs. Plates (at least three per clone) were incubated in the dark at $20{ }^{\circ} \mathrm{C}$ and radial growth was measured daily for 12 days. Differences in growth rate were analyzed with the PAST $3 \times$ software [36]. Based on southern blot and growth rate, the Geosmithia-GFP clone 3.2.2, containing one copy of the GFP gene, was chosen for the experiments.

\section{Observation of Hyphal Interactions in Fluorescence Microscopy (Experiment e)}

The interactions between the hyphae of $O . u l m i$ and ONU isolates (ONU ssp. novo-ulmi and ONU ssp. americana, Table 1) and the transformed Geosmithia sp. 5 IVV7-GFP were observed in microscope slides (three replicates for each $\mathrm{ONU} /$ Geosmithia combination) as described in experiment $\mathrm{c}$. Inoculated slides were incubated in the dark at $20{ }^{\circ} \mathrm{C}$ and observed after 2 days under UV light by fluorescence microscopy with a Leica MZ FLIII stereomicroscope (courtesy of Prof. Alessio Mengoni, Department of Biology, University of Florence), equipped with a mercury lamp and GFP filters (excitation filter at 480/40 and barrier filter at 510-nm LP), or white light to verify the autofluorescence of mycoparasite structures. Up to 100 slides per combination were examined.

\section{Fertility Tests (Experiment f)}

The effect of the presence of Geosmithia spp. on the production of perithecia in Ophiostoma spp. was assessed both in the elm system and in the non-elm (oak) system. Petri dishes (90$\mathrm{mm}$ diameter, three replicates per species combination) filled with $20 \mathrm{ml}$ of ESA were inoculated as in experiment a with two mycelial plugs, one from Geosmithia spp. and one from Ophiostoma spp. mating type A (mtA). Plates were incubated for 12 days in darkness at $20^{\circ} \mathrm{C}$, followed by 7 days in diffuse light. Spores scraped from the surface of an Ophiostoma spp. mating type $\mathrm{B}(\mathrm{mtB})$ colony that served as a donor strain were applied in $2-\mathrm{cm}^{2}$ patches (five patches per plate) to the plates containing Ophiostoma spp. $\mathrm{mtA}$ as a recipient strain in combination with Geosmithia spp. Plates were incubated for 10 days in diffuse daylight at room temperature. The presence and the number of perithecia $\left(\mathrm{no} / \mathrm{cm}^{2}\right)$ were scored under a
Nikon SMZ800 stereoscope and data analyzed by means of ANOVA (Statistica 10, StatSoft Inc.). As a control, three plates per species combination were inoculated with only the Ophiostoma mtA strain and fertilized with the respective Ophiostoma mtB strain. In the elm system, 18 Geosmithia isolates were combined with two ONU ssp. novo-ulmi and ssp. americana $\mathrm{mtA}$ isolates, respectively, and crossed with the $\mathrm{mtB}$ of the corresponding species. In the "oak system," five isolates of Geosmithia sp. 5 were tested with 5 O. quercus $\mathrm{mtA}$ isolates fertilized with a single $O$. quercus $\mathrm{mtB}$ isolate (Table 1). Fertility tests were repeated at least three times for each combination.

\section{Pathogenicity Tests (Experiment g)}

The impact of Geosmithia in the DED pathosystem was investigated in vivo by means of two pathogenicity tests carried out at the IPSP-CNR experimental nursery (Antella $\left(43^{\circ} 43^{\prime} \mathrm{N}\right.$ $11^{\circ} 22^{\prime} \mathrm{E} ; 170-\mathrm{m}$ elevation, Florence, Italy). Several Geosmithia spp. and ONU strains were inoculated alone and in combination in the elm clone Ulmus "Commelin," which was chosen for being extremely susceptible to DED [37]. Hundred five-year-old saplings growing in rows (spacing $0.5 \mathrm{~m}$ within $\times 1 \mathrm{~m}$ between rows) in a substrate comprising commercial loam to a depth of 2-m drip irrigated were inoculated. The bed was cleared and plowed prior to planting and weeded monthly thereafter. Two pathogenicity tests were performed as follows:

1) In May 2013, Ulmus Commelin (six individuals per fungal strain) was inoculated with each of seven Geosmithia spp. strains with a single wound per plant in the upper third of the main stem. Inoculations were performed following the protocol established by Santini et al. [38] for ONU inoculations, i.e., by cutting through the bark to the younger sapwood with a knife blade bearing two $0.2-\mathrm{ml}$ drops of a $1 \times 10^{6} / \mathrm{ml}$ fungal spore suspension so that the inoculum was absorbed in the sap flux.

2) In May 2014, 12 Ulmus Commelin individuals were coinoculated with the same technique as above with a spore suspension containing Geosmithia sp. 5 (IVV7) and ONU ssp. novo-ulmi "H328." The concentration of each fungus in the inoculum was adjusted to $1 \times 10^{6}$ spores $/ \mathrm{ml}$. As a control, 12 trees were inoculated with only Geosmithia sp. 5 (IVV7) and 12 trees with only ONU ssp. novo-ulmi H328. Geosmithia sp. 5 was chosen for the experiment because it is one of the most common species on elm, and IVV7 is our model strain for this species [21, 22, 39]. O. novo-ulmi ssp. novo-ulmi $\mathrm{H} 328$ is a well-known and very aggressive strain $[38,40]$. Symptoms of disease were observed at 4 weeks (percentage defoliation) and 12 months (percentage of crown dieback) after 
inoculation by three independent assessors. Pathogenicity data were analyzed by means of ANOVA (Statistica 10, StatSoft Inc.). Arcsine transformation was applied before statistical analyses to correct percentage data for departure from normality assumption.

\section{Results}

\section{Fungal Growth Rate in Dual Culture (Experiment a)}

\section{Elm System}

The growth rate of ONU strains was generally higher in dual culture with Geosmithia spp. isolated from elm than in pure culture, both on MEA and CZD (Fig. 1). In the same trial, the growth rate of Geosmithia did not show such a clear and consistent trend. Within each species, all strains grew at the same rate (non-significant Duncan test, $p>0.05$ ); therefore, different strains were used as replicates in subsequent analyses.

\section{Non-elm Systems}

Both in the oak system (O. quercus in dual culture with Geosmithia from elm, oak or other trees) and in the conifers system (Ophiostomatoid fungi from conifers in dual culture with Geosmithia from elm, conifers, or other trees), the mean radial growth in dual culture was unchanged compared to controls in all tested fungi (results not shown).

\section{Visual Examination of Mycelial Interactions (Experiment b)}

The reactions observed between the mycelia of Ophiostomatoid fungi and Geosmithia species were here classified into five main types, ranging from fully intermingling colonies to mutual growth inhibition (Table 2, Fig. 2):

Type 1, fully intermingling: complete equal bidirectional mycelial penetration. After 10 days, the two colonies were not distinguishable. Neither boundaries nor changes in color were recognizable in the mycelium.

Type 2, intermingling: the two colonies were easily recognizable, but no barrage line was visible and hyphae were intermingled along the junction line.

Type 3, mutual incompatibility: a diffuse mycelial barrage, 1 to $2 \mathrm{~mm}$ large, was clearly visible along the junction line between the two colonies;

- 3.1: diffuse mycelial barrage developed by Geosmithia spp. No visible barrage was produced by Ophiostomatoid fungi.
Fig. 1 Fungal growth rate in dual culture. Left, growth rate of Geosmithia spp. with Ophiostoma novo-ulmi ssp. novoulmi and ssp. americana on MEA $(2 \%)$ and CZD; right, growth rate of $O$. novo-ulmi ssp. novo-ulmi and ssp. americana with Geosmithia spp. on MEA (2\%) and CZD. Values sharing the same letters are not significantly different based on Duncan's test $(p \leq 0.05)$

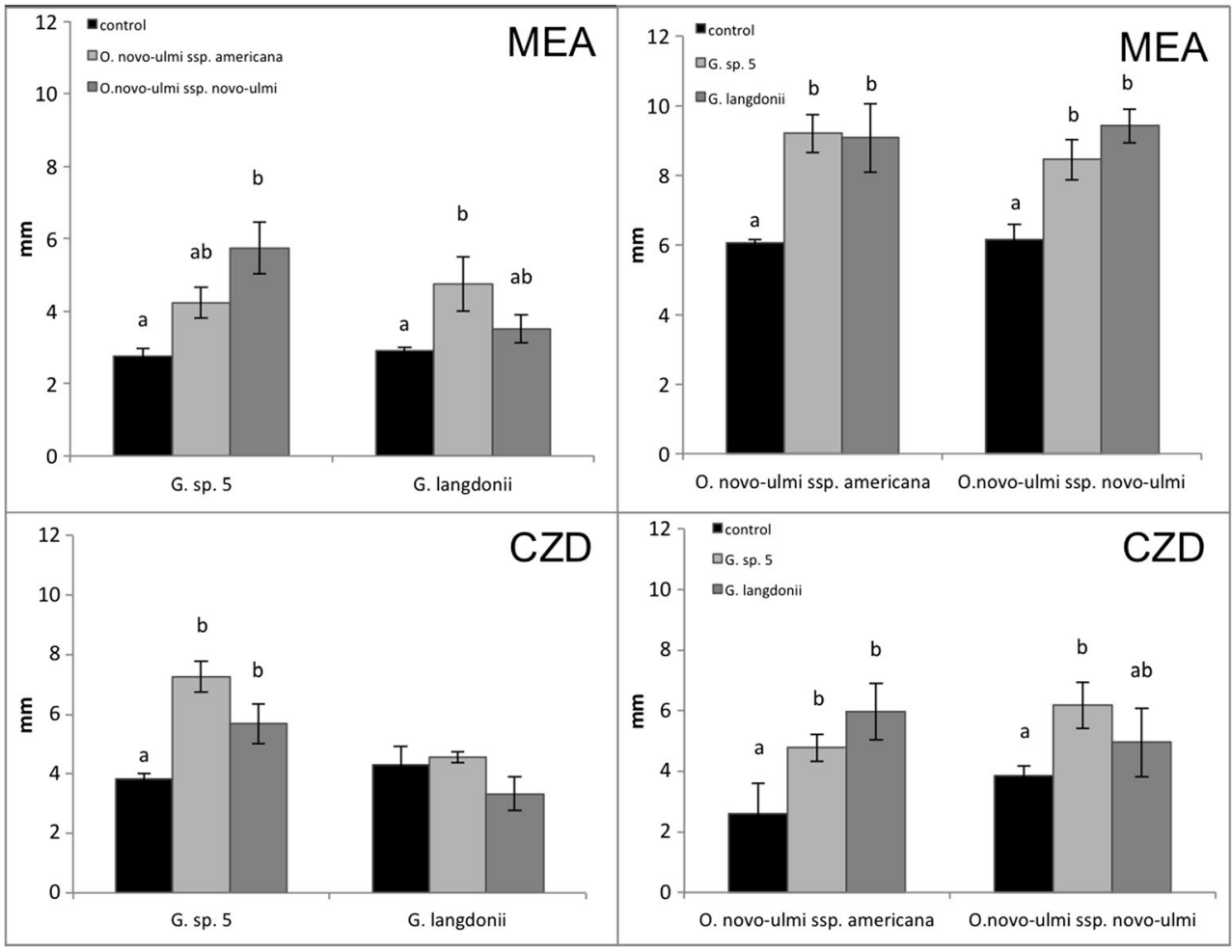




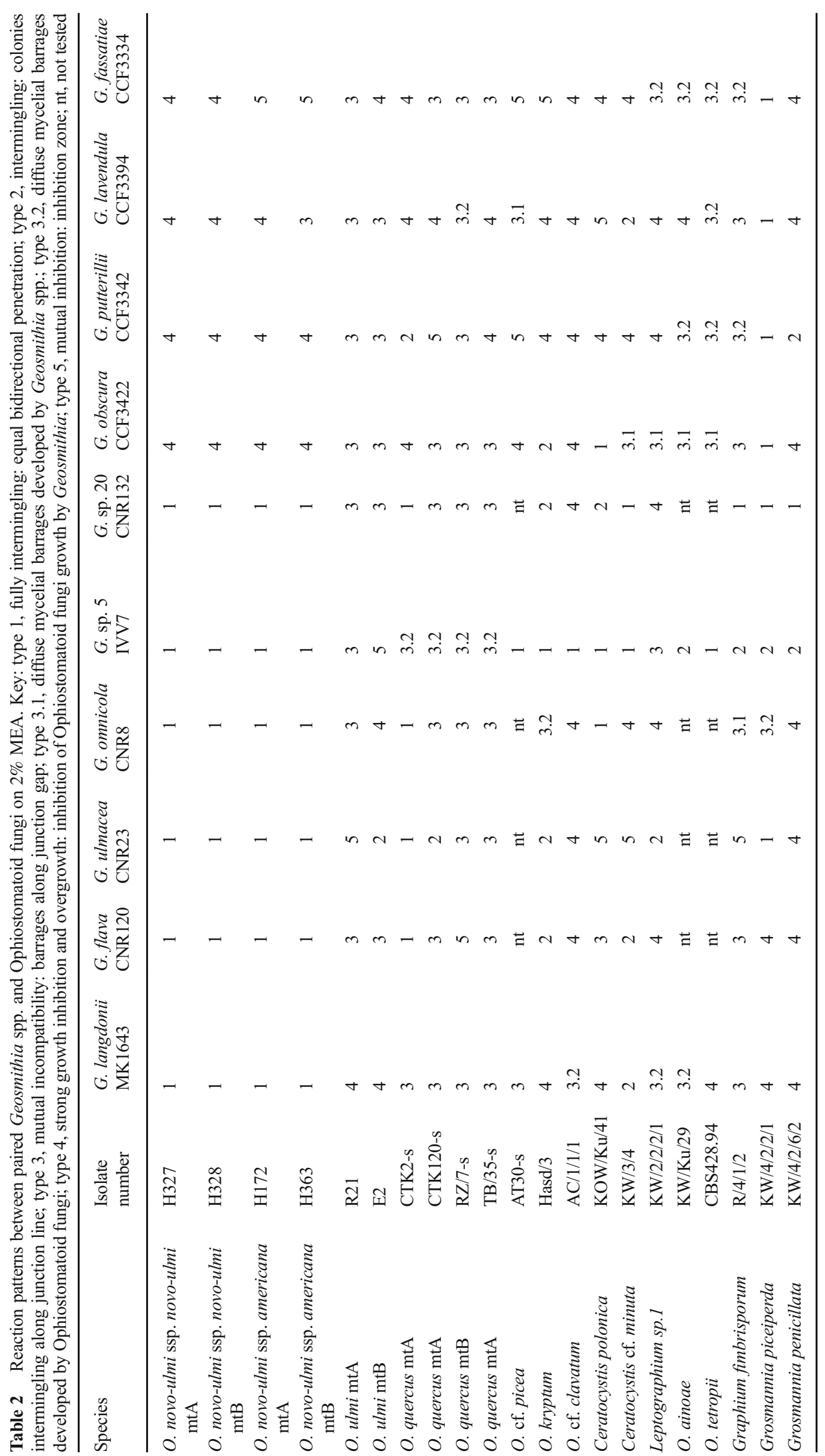


- 3.2: diffuse mycelial barrage developed by Ophiostomatoids. No visible barrage was produced by Geosmithia spp.

Type 4, strong growth inhibition and overgrowth: the growth of Ophiostomatoid fungi was inhibited at a distance of about 1-2 mm from Geosmithia hyphae, which later occupied the gap spreading eventually over the mycelium of the co-cultured Ophiostomatoid species.

Type 5, mutual inhibition: a 1-5-mm wide demarcation zone, where the aerial mycelium was missing, was visible along the confrontation line.

A fully intermingling reaction (type 1) was observed every time that two species from the elm system were grown in dual culture. Interactions between species from non-elm systems were generally characterized, with few exceptions, by various signs of mycelial inhibition, from a barrage to a wide gap along the junction line (types 3-5), revealing a recognition system between the two fungi. Compatible reactions of types 1 and 2 were observed only in dual cultures of some Ophiostomatoid fungi with Geosmithia sp. 5 IVV7 (Fig. 2).

\section{Mycoparasitic Interactions Between Geosmithia from Elm and Ophiostoma in White and Fluorescent Light Microscopy (Experiments c, e)}

Under the white light microscope, the mycelia of wild type strains of Geosmithia spp. from elm and of O. ulmi or ONU cultured together appeared to grow towards each other, with profuse hyphal growth and production of mycelial tufts (Online Resource 1). Signs of mycoparasitism by Geosmithia on Ophiostoma hyphae, such as the formation of coilings, appressoria-like branches, pseudopod-like structures, or short hooks, were common (Online Resource 1).

In the elm system, the formation by Geosmithia on Ophiostoma hyphae of structures that are typically observed during mycoparasitic attack was confirmed with increased evidence when the Geosmithia sp. 5 IVV7-GFP clone 3.2.2 was observed in dual culture with both $O$. ulmi (not shown) and ONU (Fig. 3a-c) under UV light.

\section{Fertility Test (Experiment f)}

In the elm system, ONU ssp. novo-ulmi mtA (H327) fertilized by a $\mathrm{mtB}$ strain $(\mathrm{H} 328)$ produced a significantly higher number of perithecia (Duncan test, $p<0.05$ ) in dual cultures with Geosmithia spp. isolates than in control crosses where Geosmithia was absent (Fig. 4). On the contrary, ONU ssp. americana cultivated with Geosmithia spp. did not produce perithecia after fertilization with the opposite mating type.

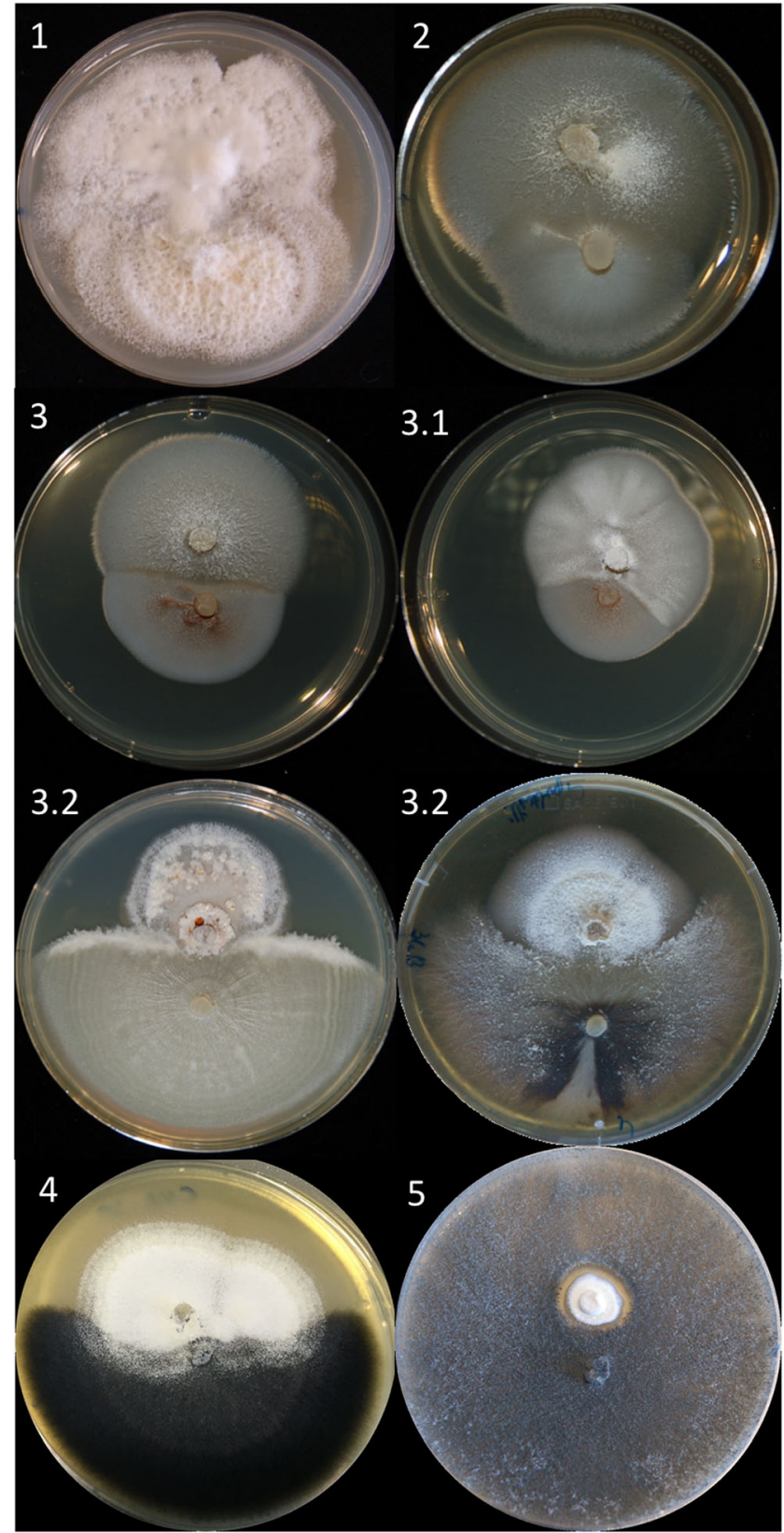

Fig. 2 Type of mycelial interactions on MEA (2\%) (the mycelium at the figure's top belongs to Geosmithia spp. in all cases): type 1, G. omnicola (CNR8)-Ophiostoma novo-ulmi ssp. novo-ulmi (H327); type 2, G. flava (CNR120)-Ceratocystis minuta (KW/3/4); type 3, G. flava (CNR120)Rhexographium fimbriasporum (R/4/1/2); type 3.1, G. omnicola (CNR8)-Rhexographium fimbriasporum (R/4/1/2); type 3.2, G. obscura (CCF3422)-O. ulmi (E2); type 3.2, G. putterillii (CCF3342)-Ophiostoma ainoae $(\mathrm{KW} / \mathrm{Ku} / 29)$; type 4 , G. flava (CNR120)-Ophiostoma clavatum (AC/1/1/1); type 5, G. ulmacea (CNR23)-Endoconidiophora polonica (KOW/Ku/41). The different types of mycelial interaction are described in the "Results" section (experiment b)

In the oak system instead, all strains of O. quercus mtA fertilized with opposite $\mathrm{mtB}$ isolates produced an equal number of perithecia whether or not they were grown in dual culture with Geosmithia sp. 5 (results not shown). 
Fig. 3 a-c Interacting hyphae of Ophiostoma novo-ulmi (ONU) and Geosmithia sp. 5 "IVV7"GFP (IVV7T). On the left both species are observed under white light, while on the right only Geosmithia hyphae are visible in UV light (under UV light a green specific signal is due to the GFP transformation). Arrows indicate possible parasitic structures formed by Geosmithia

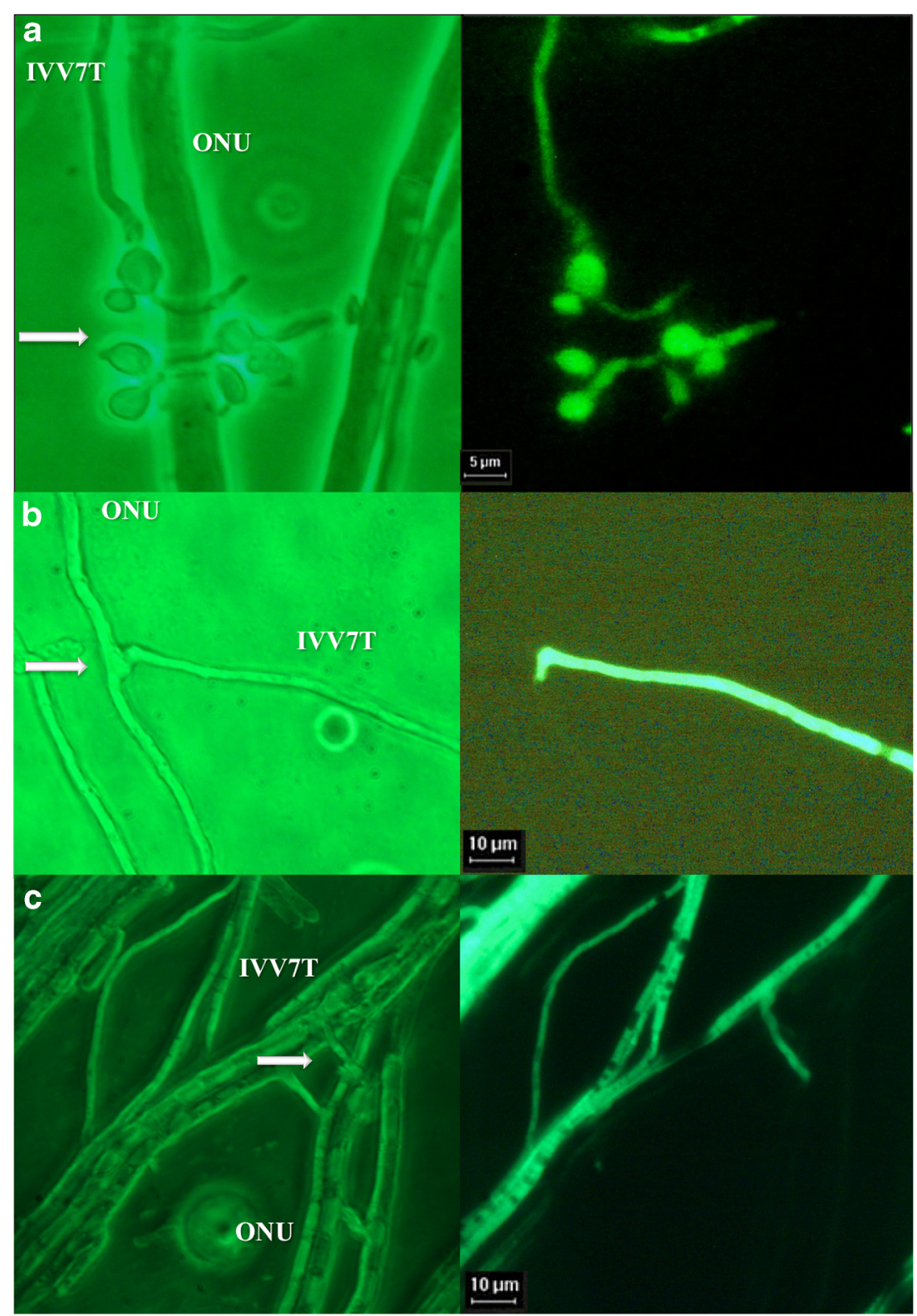

\section{Pathogenicity Tests (Experiment g)}

The addition of spores of Geosmithia species to the suspension of ONU spores used for artificial inoculations reduced DED symptoms, both defoliation (4 weeks after inoculation, Duncan test $p \leq 0.05$ ) and dieback (12 months after inoculation, Duncan test $p \leq 0.05$ ), in the elm clone Ulmus Commelin compared to controls inoculated with ONU alone (Table 3). While inoculation with ONU produced severe DED symptoms, elms remained substantially asymptomatic after inoculation with only Geosmithia (Table 3), regardless of the Geosmithia species applied (results not shown).

In particular, 12 months after inoculation, when the plant reaction is stable and can be considered as conclusive, dieback was much more severe in the plants inoculated with ONU alone than in the plants co-inoculated with ONU and Geosmithia spp. (55.5 vs. $17.6 \%$, respectively). O. novo-ulmi was always successfully re-isolated from xylem of inoculated trees, while none of the Geosmithia species used was reisolated.

\section{Discussion}

Millions of elms vanished from Europe and North America over the last 100 years because the alien fungi responsible for DED established in the areas of introduction a new association with native EBBs that became extremely efficient vectors of the disease. The same beetles also have a high-fidelity association with fungi of the genus Geosmithia [16]. 


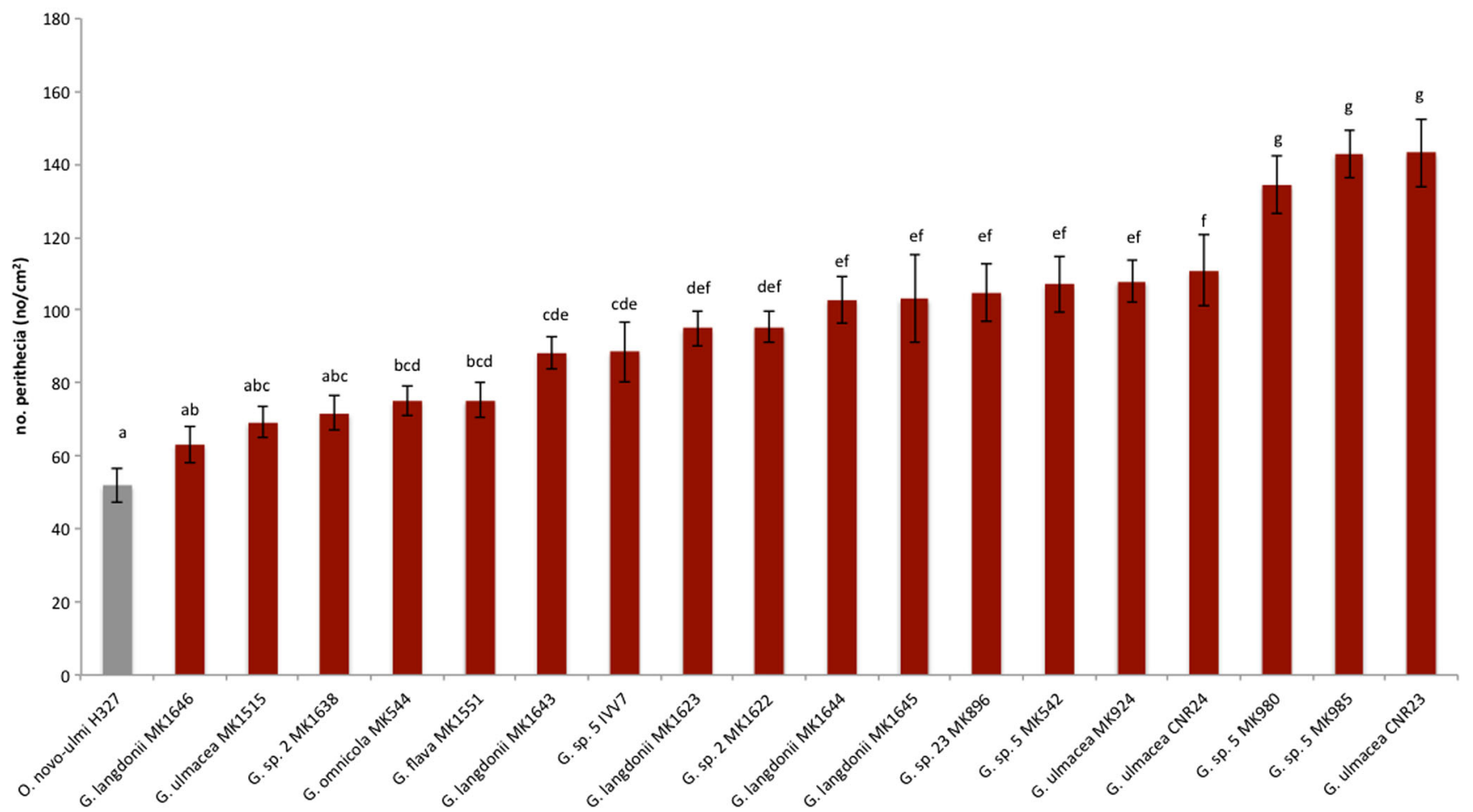

Fig. 4 Fertility test between species from the "elm system." The number of perithecia formed by Ophiostoma spp. in dual-culture with Geosmithia spp. is shown in red, while gray bars correspond to the control. Duncan's

Geosmithias are generally considered as saprotrophs or endophytes [17]. However, in elms, they have never been isolated from dead wood or from healthy trees, but they were only found in beetles' galleries [21]. High frequency HGT of the cerato-ulmin ( $\mathrm{cu}$ ) gene between ONU and Geosmithia spp. [22] suggests that between the two species exists a relationship that goes beyond simple sharing of habitat and vectors and is much closer.

The present study provides direct and indirect evidence of mycoparasitism on ONU by many Geosmithia isolates specific to the elm system. Should this be the case, it might be concluded that the transfer of the $c u$ gene observed between ONU and Geosmithia may be described as prey-derived HGT. The integration into the genome of sequences derived from organisms consumed as food has frequently been reported, leading to the "you are what you eat" hypothesis [41], both in phagotrophic eukaryotes harboring genes from food sources $[42,43]$ and in prokaryotes such as the bacteriolytic Bdellovibrio bacteriovorus HD100 [44, 45].

The higher growth rate observed in ONU in dual culture with Geosmithia might be regarded as a sort of "escape in space" (sensu Janzen) [46] of ONU from Geosmithia towards an area free from the "enemy." The absence of mycelial interaction between Geosmithia and ONU is consistent with the hypothesis that the two organisms represent a newly formed host-pathogen system. In the oak system and in the conifers test was applied to test for differences in means. Values sharing the same letters are not significantly different $(p \leq 0.05)$

system, recognition between Geosmithia spp. and Ophiostomatoid fungi was the norm, with very few exceptions. A weak intermingling reaction with no mycelial barrages along the junction line was observed in dual culture (1) between Geosmithia sp. 5 IVV7 and many Ophiostomatales, (2) in all the combinations of Geosmithia spp. with Ophiostomatoid fungi in non-elm systems, and (3) when Geosmithia sp. 20 was co-cultured with Leptographium piceaperdum, the most common Ophiostomatales species associated with spruce beetles [47]. In no instance, however, structures typical of parasitic behavior were formed in these combinations.

Therefore, Geosmithia parasitic behavior seems to be specific to the elm system. In fact, in most of the non-elm systems challenged here, similar interactions were not observed. If this hypothesis proves true, then IVV7 is the isolate displaying the most evident mycoparasitic behavior. This behavior explains its ability to overtake the host defense mechanisms and to grow over it. In this system, ONU represents a widely available carbon source exploitable by Geosmithia fungi.

Comparing the present results with what is known for Trichoderma, a fungal genus well known as a mycoparasite and biocontrol agent [48-51], several similarities can be identified. Trichoderma attraction to and growth towards its host seems to be stimulated at a distance by the recognition of diffusible signals, such as oligochitins [52]. Mycoparasitism 
Table 3 Pathogenicity test. Mean disease scores not sharing a common letter differ significantly by Duncan's test $(p<005) . N$ number of tested isolates, mean $\%$ mean percentage of symptoms, SE standard error

\begin{tabular}{|c|c|c|c|c|c|c|c|}
\hline & \multirow[t]{2}{*}{$N$} & \multicolumn{3}{|l|}{4 weeks } & \multicolumn{3}{|l|}{12 months } \\
\hline & & Mean defoliation $\%$ & SE & & Mean dieback $\%$ & SE & \\
\hline O. novo-ulmi & 20 & 24.210 & 3.109 & a & 55.518 & 7.255 & $\mathrm{a}$ \\
\hline O. novo-ulmi + Geosmithia sp. 5 & 20 & 18.329 & 2.330 & $\mathrm{~b}$ & 17.658 & 6.622 & $\mathrm{~b}$ \\
\hline Geosmithia sp. 5 & 60 & 2.014 & 0.854 & $\mathrm{c}$ & 1.084 & 0.577 & $\mathrm{~b}$ \\
\hline
\end{tabular}

in Trichoderma spp. involves hydrophobins and hydrophobin-like proteins, such as cerato-platanins. Class II hydrophobins HYTLO1 and TvHydII1, isolated respectively from Trichoderma longibrachiatum MK1 [53] and T. viride [54], are required for mycoparasitic activity against phytopathogenic fungi to grow over their hosts. Trichoderma harzianum cerato-platanin Epl-1 [50, 55] also has key functions in the mycoparasitic process, as a self-recognition factor or by modulating hyphal coiling and mycoparasitism-related gene expression, and in the interaction with the host plant [55].

Similarly, in the Geosmithia-ONU system, the attraction signal seems to act at a distance without physical contact. Upon contact, Geosmithia hyphae coil around or grow along ONU hyphae, forming appressoria-like structures that may be used for penetrating ONU (Fig. 4). Geosmithia fungi produce a class II hydrophobin, GEO1, which could be involved in the attachment to other hydrophobic structures, e.g., insect exoskeleton and hyphae of other fungi $[25,56]$. The mode of action and the mechanisms involved in the GeosmithiaONU-elm interaction are still unknown, but GEO1 might play a similar role as Trichoderma hydrophobins and Epl-1, promoting mycoparasitic activity and inducing local and systemic defenses in plants [53-55].

Brasier [57-59] showed that Trichoderma could trigger sexual reproduction in many isolates of the Phytophthora A2 compatibility group by producing volatile antibiotics, an effect which is more likely a defense mechanism specifically evolved in Phythopthora than an incidental phenomenon. In the present study, Geosmithia spp. tested in fertility trials showed on ONU a similar effect as Trichoderma spp. on Phytophthora. Within the elm system, Geosmithia was shown to induce a significantly higher production of proto-perithecia in all isolates of ONU mtA and of perithecia when fertilized by the opposite mtB. A possible interpretation is that Geosmithia (predator) stimulates in ONU (prey) the "escape from the predator in time" [46] reaction, possibly increasing the evolutionary potential of ONU populations by boosting sexual reproduction and recombination. Such an effect was not observed in the oak system.

Artificial inoculation with ONU resulted in typical symptoms of DED in elms, while no sign of disease was observed when Geosmithia alone was inoculated. In the case of coinfection, the presence of Geosmithia reduces DED symptoms. This could be attributed either to its mycoparasitic activity or to the enhancement of defense mechanisms in elm. A similar effect is well known in Trichoderma fungi that not only protect plants directly by killing other fungi and nematodes but also induce resistance against plant pathogens [51]. Based on these results, Geosmithia is not a pathogen on elm, in contrast with the observation by Hänzi et al. [60]. In no case, we were able to re-isolate Geosmithia from artificially infected elms, nor was it reported among the endophytic cohort of saprotrophs of elm trees [61]. The amount of the fungus in elm tissues could be too low to be detected with standard techniques and require a more sensitive method such as a specific qPCR assay. It could as well be moved to a district of the tree different from the xylem.

If mycotrophy towards many plant pathogenic fungi has long been the original lifestyle of Trichoderma, in Geosmithia, it appears to be a recent event. The DED epidemics that occurred in Europe during the past century created the conditions for Geosmithia development, reproduction, and dissemination by increasing the number of suitable habitats for both ONU and Geosmithia spp. These conditions may have favored the discovery and systematic study of the genus Geosmithia by the scientific community [13]. This hypothesis is supported by the finding that the $c u$ gene was transferred to Geosmithia from ONU, but not from O. ulmi [22]. As the appearance of ONU in Europe can be dated at around the 1960s [2], HGT between the two fungi should be a very recent and currently ongoing event in Europe. The lack of recognition between Geosmithia and ONU in the elm system confirms that they were geographically isolated and interacted only recently. The $c u$ gene was not found in any of the Geosmithia isolates obtained from the non-elm system.

A DED epidemic outbreak is governed by the population dynamics of the host, the pathogen and its vector, and also by the rate of sexual reproduction of the pathogen, which can influence the risk of fungus viral disease outcome and, lastly, by the presence of mycoparasitic fungi as Geosmithia species [22].

The system can be described as a classical Lotka-Volterra model in which the predator, ONU, supported by beetles as vectors, consumes the prey, leading to depletion of elm population and, consequently, of both the predator and the vector populations. When the predator population is low, the prey is able to thrive, thereby putting the ecosystem through cycles of "boom-and-bust." In the long run, the intervention of new factors may lead to stabilization of the population dynamics. 
Many polyphagous organisms are able to switch to different carbon sources over time in response to variation in the local ecosystem. Therefore, as ONU became more and more abundant in the community (getting in contact more frequently with organisms sharing the same habitat and vectors), we expect that another organism, even mildly pathogenic as Geosmithia, might have adapted to attack this new host species and reproduce on it, which would lead to an increased degree of parasitism [62].

In the early 1980s, many researchers focused on possible agents of biological control of DED as bacteria [47, 63-70]. Unfortunately, none of these authors could provide evidence that any of these microorganisms might become a successful and widespread competitor or parasite of DED fungi. The main reasons for these drawbacks are that these antagonistic species either are limited by environmental factors [69] or have no vectors able to spread them. On the contrary, Geosmithia species benefit from a widespread distribution and a strict association with effective insect vectors.

Here, it was shown that Geosmithia is an important element in the DED network, making it even more complex, yet probably less detrimental for elms, and more stable over time. There is increasing evidence that the health or disease status of a given organism is not just the result of the interaction between host and pathogen but depends on a complex interaction between each partner and its microbial community (holobiont), which in the end determines the outcome of the infection. Therefore, the fate of the infected elm is not determined only by ONU, but it rather depends on the DED network which may be defined as a holobiont, i.e., the totality of all beings involved comprising ONU, d-factor viruses, EBBs, mites, and also Geosmithia.

Moreover, as Geosmithias living in the elm system are able to mycoparasitize ONU and to reduce DED symptoms in artificially inoculated plants, these fungi might be used as biocontrol agents against ONU. Further research is certainly needed to assess the mechanisms that allow Geosmithias, when co-inoculated with ONU, to attenuate DED symptoms, and to define both how to exploit this effect and how to artificially spread "elm Geosmithias." However, such a holistic approach would reinforce the conviction that a different management of diseases in natural ecosystems is possible.

Acknowledgements The authors wish to warmly thank all the colleagues who have provided fungal strains, Mr. Andrew Brookes (University of Portsmouth, UK), and Dr. Lorenzo Bonosi for English language editing of the manuscript.

Funding Information This research was funded by PRIN Project 2009 RZ94KA_003, Ministry of University and Research (Italy).

\section{Compliance with Ethical Standards}

Conflict of Interest The authors declare that they have no conflict of interest.
Open Access This article is distributed under the terms of the Creative Commons Attribution 4.0 International License (http:// creativecommons.org/licenses/by/4.0/), which permits use, duplication, adaptation, distribution and reproduction in any medium or format, as long as you give appropriate credit to the original author(s) and the source, provide a link to the Creative Commons license, and indicate if changes were made.

\section{References}

1. Six DL (2013) The bark beetle holobiont: why microbes matter. J. Chem. Ecol. 39:989-1002. https://doi.org/10.1007/s10886-0130318-8

2. Brasier CM (1991) Ophiostoma novo-ulmi sp. nov., causative agent of current Dutch elm disease pandemics. Mycopathologia 115:151161. https://doi.org/10.1007/BF00462219

3. Fransen JJ (1939) Iepenziekte Iepenspintkevers an beider bestrijding [elm disease, elm beetles and their control]. Dissertation, Wageningen Agricultural College,

4. Santini A, Faccoli M (2015) Dutch elm disease and elm bark beetles: a century of association. iForest 8:126-134. https://doi.org/10. 3832/ifor1231-008

5. Moser JC, Konrad H, Blomquist SR, Kirisits T (2010) Do mites phoretic on elm bark beetles contribute to the transmission of Dutch elm disease? Naturwissenschaften 97:219-227. https://doi.org/10. 1007/s00114-009-0630-x

6. Brasier CM (1983) A cytoplasmically transmitted disease of Ceratocystis ulmi. Nature 305:220-223. https://doi.org/10.1038/ 305220a0

7. Webber JF (1987) Influence of the $\mathrm{d} 2$ factor on survival and infection by the Dutch elm disease pathogen Ophiostoma ulmi. Plant Pathol. 36:531-538. https://doi.org/10.1111/j.1365-3059.1987. tb02270.x

8. Brasier CM (1986) The d-factor in Ceratocystis ulmi-its biological characteristics and implications for Dutch elm disease. In: Buck KW (ed) Fungal Virology. CRC Press, Boca Raton, Florida, USA, pp. $177-208$

9. Brasier CM (2000) Viruses as biological control agents of the Dutch elm disease fungus Ophiostoma novo-ulmi. In: Dunn CP (ed) The elms. Breeding, conservation, and disease management. Springer, New York, pp. 201-212. https://doi.org/10.1007/978-1-4615-4507112

10. Paoletti M, Buck KW, Brasier CM (2006) Selective acquisition of novel mating type and vegetative incompatibility genes via interspecies gene transfer in the globally invading eukaryote Ophiostoma novo-ulmi. Mol. Ecol. 15:249-262. https://doi.org/ 10.1111/j.1365-294X.2005.02728.x

11. Buck KW, Brasier CM (2002) Viruses of the Dutch elm disease fungi. In: Tavantzis SM (ed) dsRNA genetic elements: concepts and applications in agriculture, forestry and medicine. CRC Press, Boca Raton, pp. 165-190

12. Brasier CM, Kirk SA (2010) Rapid emergence of hybrids between the two subspecies of Ophiostoma novo-ulmi with a high level of pathogenic fitness. Plant Pathol. 59:186-199. https://doi.org/10. $1111 /$ j.1365-3059.2009.02157.x

13. Pitt JI (1979) Geosmithia gen. nov. for Penicillium lavendulum and related species. Can. J. Bot. 57:2021-2030. https://doi.org/10.1139/ b79-252

14. Kolařík M, Kubátová A, Pažoutová S, Šrůtka P (2004) Morphological and molecular characterisation of Geosmithia putterillii, G. pallida comb. nov. and G. flava sp. nov., associated with subcorticolous insects. Mycol. Res. 108:1053-1069. https:// doi.org/10.1017/S0953756204000796 
15. Kolaøík M, Kubátová A, Cepicka I, Pažoutová S, Šrùtka P (2005) A complex of three new whitespored, sympatric, and host range limited Geosmithia species. Mycol Res 109:1323-1336. https:// doi.org/10.1017/S0953756205003965

16. Kolařík M, Kostovčík M, Pažoutová S (2007) Host range and diversity of the genus Geosmithia (Ascomycota: Hypocreales) living in association with bark beetles in the Mediterranean area. Mycol. Res. 111:1298-1310. https://doi.org/10.1016/j.mycres.2007.06.010

17. Kolař́k M, Kubátová A, Hulcr J, Pažoutová S (2008) Geosmithia fungi are highly diverse and consistent bark beetle associates: evidence from their community structure in temperate Europe. Microb. Ecol. 55:65-80. https://doi.org/10.1007/s00248-007-9251-0

18. Kolařík M, Freeland M, Utlet C, Tisserat N (2011) Geosmithia morbida sp. nov., a new phytopathogenic species living in symbiosis with the walnut twig beetle (Pityophthorus juglandis) on Juglans in USA. Mycologia 103:325-332. https://doi.org/10. 3852/10-124

19. Kolařík M, Jankowiak R (2013) Vector affinity and diversity of Geosmithia fungi living on subcortical insects inhabiting Pinaceae species in Central and Northeastern Europe. Microb. Ecol. 66:682700. https://doi.org/10.1007/s00248-013-0228-x

20. McPherson BA, Erbilgin N, Bonello P, Wood DL (2013) Fungal species assemblages associated with Phytophthora ramorum-infected coast live oaks following bark and ambrosia beetle colonization in northern California. Forest Ecol Manag 291:30-42. https:// doi.org/10.1016/j.foreco.2012.11.010

21. Pepori AL, Kolařík M, Bettini PP, Vettraino AM, Santini A (2015) Morphological and molecular characterisation of Geosmithia species on European elms. Fungal Biol 119:1063-1074. https://doi. org/10.1016/j.funbio.2015.08.003

22. Bettini PP, Frascella A, Kolařík M, Comparini C, Pepori AL, Santini A, Scala F, Scala A (2014) Widespread horizontal transfer of the cerato-ulmin gene between Ophiostoma novo-ulmi and Geosmithia species. Fungal Biol 118:663-674. https://doi.org/10. 1016/j.funbio.2014.04.007

23. Scala F, Bertelli E, Coppola L, Del Sorbo G, Tegli S, Scala A (1997) Comparative determination of cerato-ulmin on cell surface and in mycelial extracts of pathogenic and non-pathogenic Ophiostoma species. Mycol. Res. 101:829-834. https://doi.org/10.1017/ S0953756296003358

24. Carresi L, Comparini C, Bettini PP, Pazzagli L, Cappugi G, Scala F, Scala A (2008) Isolation of the orthologue of the cerato-ulmin gene in Ophiostoma quercus and characterization of the purified protein. Mycol. Res. 112:1245-1255. https://doi.org/10.1016/j.mycres. 2008.05.005

25. Temple B, Horgen PA (2000) Biological roles for cerato-ulmin, a hydrophobin secreted by the elm pathogens, Ophiostoma ulmi and O. novo-ulmi. Mycologia 92:1-9

26. Cizková D, Sřũtka P, Kolařík M, Kubátová A, Pažoutová S (2005) Assessing the pathogenic effect of Fusarium, Geosmithia and Ophiostoma fungi from broad-leaved trees. Folia Microbiol 50: 59-62. https://doi.org/10.1007/BF02931294

27. Bettini PP, Baraldi R, Rapparini F, Melani L, Mauro ML, Bindi D, Buiatti M (2010) The insertion of the Agrobacterium rhizogenes rolC gene in tomato (Solanum lycopersicum L.) affects plant architecture and endogenous auxin and abscisic acid levels. Sci Hort 123:323-328. https://doi.org/10.1016/j.scienta.2009.09.013

28. Wingfield MJ, Barnes I, de Beer ZW, Roux J, Wingfield BD, Taerum SJ (2017) Novel associations between ophiostomatoid fungi, insects and tree hosts: current status-future prospects. Biol. Invasions. https://doi.org/10.1007/s10530-017-1468-3

29. Brasier CM (1981) Laboratory investigation of Ceratocystis ulmi. In: Stipes RJ, Campana RJ (eds) Compendium of elm diseases. American Phytopathological Society, St Paul, pp. 76-79

30. Pipe ND, Buck KW, Brasier CM (1995) Molecular relationships between Ophiostoma ulmi and the NAN and EAN races of O. novo-ulmi determined by RAPD markers, Mycol Res 99:653658. https://doi.org/10.1016/S0953-7562(09)80522-4

31. Gibbs, J. N., Brasier, C. M., McNabb, H. S. and Heybroek, H. M. (1975), Further studies on pathogenicity in Ceratocystis ulmi. Eur J For Pathol 5:161-174. https://doi.org/10.1111/j.1439-0329.1975. tb00461.x

32. Brasier CM (1984) Inter-mycelial recognition systems in Ceratocystis ulmi: their physiological properties and ecological importance. In: Jennings DH, Rayner ADM (eds) The ecology and physiology of the fungal mycelium. Cambridge University Press, London, pp. 451-497

33. Punja ZK, Grogan RG (1983) Hyphal interactions and antagonism among field isolates and single-basidiospore strains of Athelia (Sclerotium) rolfsii. Phytopathology 73:1279-1284

34. Sesma A, Osbourn AE (2004) The rice leaf blast pathogen undergoes developmental processes typical of root-infecting fungi. Nature 431:582-586. https://doi.org/10.1038/nature02880

35. Sarrocco S, Falaschi N, Vergara M, Nicoletti F, Vannacci G (2007) Use of Fusarium oxysporum f. sp. dianthi transformed with marker genes to follow colonization of carnation roots. J. Plant Pathol. 89: $61-68$

36. Hammer Ø, Harper DAT, Ryan PD (2001) PAST: paleontological statistics software package for education and data analysis. Palaeontol. Electron. 4(1):1-9

37. Heybroek HM (1993) The Dutch elm breeding program. In: Sticklen MB, Sherald JL (eds) Dutch elm disease research. Springer, New York, pp. 16-25. https://doi.org/10.1007/978-14615-6872-8_3

38. Santini A, Fagnani A, Ferrini F, Ghelardini L, Mittempergher L (2005) Variation among Italian and French elm clones in their response to Ophiostoma novo-ulmi inoculation. Forest Pathol 35: 183-193. https://doi.org/10.1111/j.1439-0329.2005.00401.x

39. Scala A, Comparini C, Tegli S, Scala F (2007) A non-Ophiostoma fungus expresses the gene encoding the hydrophobin cerato-ulmin. J. Plant Pathol. 89:233-240. https://doi.org/10.4454/jpp.v89i2.748

40. Brasier CM (1986) Comparison of pathogenicity and cultural characteristics in the EAN and NAN aggressive subgroups of Ophiostoma ulmi. T Brit Mycol Soc 87:1-13. https://doi.org/10. 1016/S0007-1536(86)80001-8

41. Doolittle WF (1998) You are what you eat: a gene transfer ratchet could account for bacterial genes in eukaryotic genomes. Trends Genet. 14:307-311. https://doi.org/10.1016/S0168-9525(98) 01494-2

42. Loftus BJ, Fung E, Roncaglia P, Rowley D, Amedeo P, Bruno D, Allen JE (2005) The genome of the basidiomycetous yeast and human pathogen Cryptococcus neoformans. Science 307:13211324. https://doi.org/10.1126/science. 1103773

43. Yue J, Hu X, Huang J (2013) Horizontal gene transfer in the innovation and adaptation of land plants. Plant Signal. Behav. 8:e24130. https://doi.org/10.4161/psb.24130

44. Rendulic S, Jagtap P, Rosinus A, Eppinger M, Baar C, Lanz C, Keller H, Lambert C, Evans KJ, Goesmann A, Meyer F, Sockett RE, Schuster SC (2004) A predator unmasked: life cycle of Bdellovibrio bacteriovorus. Science 303:689-692. https://doi.org/ 10.1126/science.1093027

45. Gophna U, Charlebois RL, Doolittle WF (2006) Ancient lateral gene transfer in the evolution of Bdellovibrio bacteriovorus. Trends Microbiol. 4:64-69. https://doi.org/10.1016/j.tim.2005.12. 008

46. Janzen DH (1971) Escape of Cassia grandis L. beans from predators in time and space. Ecology 6:964-979. https://doi.org/10.2307/ 1933802

47. Jankowiak R, Kacprzyk M, Młynarczyk M (2009) Diversity of ophiostomatoid fungi associated with bark beetles (Coleoptera: Scolytidae) colonizing branches of Norway spruce (Picea abies) 
in southern Poland. Biologia 64:1170-1177. https://doi.org/10. 2478/s11756-009-0188-2

48. Viterbo A, Horwitz BA (2010) Mycoparasitism. In: Borkovich K, Ebbole DJ (eds) Cellular and molecular biology of filamentous fungi. ASM Press, Washington DC, pp. 676-693. https://doi.org/ 10.1128/9781555816636.ch42

49. Matarese F, Sarrocco S, Gruber S, Seidl-Seiboth V, Vannacci G (2012) Biocontrol of Fusarium head blight: interactions between Trichoderma and mycotoxigenic Fusarium. Microbiology 158:98106. https://doi.org/10.1099/mic.0.052639-0

50. Mukherjee PK, Horwitz BA, Herrera-Estrella A, Schmoll M, Kenerley CM (2013) Trichoderma research in the genome era. Annu. Rev. Phytopathol. 51:105-129. https://doi.org/10.1146/ annurev-phyto-082712-102353

51. Lorito M, Woo SL (2015) Trichoderma: a multi-purpose tool for integrated pest management. In: Lugtenberg B (ed) Principles of plant-microbe interactions. Microbes for sustainable agriculture. Springer International Publishing, Cham, pp. 345-353. https://doi. org/10.1007/978-3-319-08575-3 36

52. Cortes C, Gutierrez A, Olmedo V, Inbar J, Chet I, Herrera-Estrella A (1998) The expression of genes involved in parasitism by Trichoderma harzianum is triggered by a diffusible factor. Mol Gen Genet 260:218-225. https://doi.org/10.1007/s004380050889

53. Ruocco M, Lanzuise S, Lombardi N, Woo SL, Vinale F, Marra R, Varlese R, Manganiello G, Pascale A, Scala V, Turrà D, Scala F, Lorito M (2015) Multiple roles and effects of a novel Trichoderma hydrophobin. Mol. Plant-Microbe Interact. 28:167-179. https://doi. org/10.1094/MPMI-07-14-0194-R

54. Guzmán-Guzmán P, Alemán-Duarte MI, Delaye L, Herrera-Estrella A, Olmedo-Monfil V (2017) Identification of effector-like proteins in Trichoderma spp. and role of a hydrophobin in the plant-fungus interaction and mycoparasitism. BMC Genet. 18:16. https://doi.org/ 10.1186/s12863-017-0481-y

55. Gomes EV, do Nascimento Costa M, de Paula RG, Ricci de Azevedo R, Lopes da Silva F, Noronha EF, Ulhoa CJ, Monteiro VN, Cardoza RE, Gutiérrez S, Nascimento Silva R (2015) The Cerato-Platanin protein Epl-1 from Trichoderma harzianum is involved in mycoparasitism, plant resistance induction and self cell wall protection. Sci Rep 5:17998. https://doi.org/10.1038/ srep17998

56. Bettini PP, Frascella A, Comparini C, Carresi L, Pepori AL, Pazzagli L, Cappugi G, Scala F, Scala A (2012) Identification and characterization of GEO1, a new class II hydrophobin from Geosmithia spp. Can. J. Microbiol. 58:965-972. https://doi.org/ 10.1139/w2012-069

57. Brasier CM (1971) Induction of sexual reproduction in single A2 isolates of Phytophthora species by Trichoderma viride. Nature 231:283-283. https://doi.org/10.1038/newbio231283a0
58. Brasier CM (1975) Stimulation of sex organ formation in Phytophthora by antagonistic species of Trichoderma. I. The effect in vitro. New Phytol. 74:183-194. https://doi.org/10.1111/j.14698137.1975.tb02604.x

59. Brasier CM (1975) Stimulation of sex organ formation in Phytophthora by antagonistic species of Trichoderma. II. Ecological implications. New Phytol. 74:195-198. https://doi.org/10.1111/j. 1469-8137.1975.tb02605.x

60. Hänzi M, Cochard B, Chablais R, Crovadore J, Lefort F (2016) First report of Geosmithia langdonii and Geosmithia spp. isolated from a decaying elm (Ulmus minor) in Geneva, Switzerland. Folia Forestalia Polonica 58:96-102. https://doi.org/10.1515/ffp-20160011

61. Martin JA, Witzell J, Blumenstein K, Rozpedowska E, Helander M, Sieber TN, Gil L (2013) Resistance to Dutch elm disease reduces presence of xylem endophytic fungi in elms (Ulmus spp.). PLoS One 8:e56987. https://doi.org/10.1371/journal.pone.0056987

62. Gilbert GS, Parker IM (2010) Rapid evolution in a plant pathogen interaction and the consequences for introduced host species. Evol. Appl. 3:144-156. https://doi.org/10.1111/j.1752-4571.2009.00107.x

63. Lam BS, Strobel GA, Harrison LA, Lam ST (1987) Transposon mutagenesis and tagging of fluorescent Pseudomonas: Antimycotic production is necessary for control of Dutch elm disease. Proc. Natl. Acad. Sci. U. S. A. 84:6447-6451

64. Myers DF, Strobel GA (1983) Pseudomonas syringae as a microbial antagonist against C. ulmi in the apoplast of American elms. T Brit Mycol Soc 80:389-394. https://doi.org/10.1016/S00071536(83)80034-5

65. Scheffer RJ (1983) Biological control of Dutch elm disease by Pseudomonas species. Ann Appl Biol 103:21-30. https://doi.org/ 10.1111/j.1752-4571.2009.00107.x

66. Scheffer RJ, Strobel GA (1988) Dutch elm disease, a model tree disease for biological control. In: Mukerji KG, Garg KL (eds) Biocontrol of plant diseases, vol II. CRC Press, Boca Raton, pp. 103-119

67. Strobel GA, Lanier GN (1981) Dutch elm disease. Sci. Am. 245: 56-66. https://doi.org/10.1038/scientificamerican0881-56

68. Webber JF (1981) A natural biological control of Dutch elm disease. Nature 292:449-451. https://doi.org/10.1038/292449a0

69. Webber JF, Gibbs J (1984) Colonization of elm bark by Phomopsis oblonga. T Brit Mycol Soc 82:348-352. https://doi.org/10.1016/ S0007-1536(84)80083-2

70. Webber JF, Hedger JN (1986) Comparison of interactions between Ceratocystis ulmi and elm bark saprobes in vitro and in vivo. T Brit Mycol Soc 86:93-101. https://doi.org/10.1016/S0007-1536(86) 80120-6 